\title{
Cholesterol sulphate affects production of steroid hormones by reducing steroidogenic acute regulatory protein level in adrenocortical cells
}

\author{
Teruo Sugawara', Eiji Nomura ${ }^{2}$ and Nobuhiko Hoshi ${ }^{3}$ \\ Departments of ${ }^{1}$ Biochemistry and ${ }^{2}$ Obstetrics and Gynecology, Hokkaido Graduate School of Medicine, Kita-ku, Kita 15, Nishi 7, Sapporo 060-8638, Japan \\ ${ }^{3}$ Department of Bioresource and Agrobiosciences, Graduate School of Science and Technology, Kobe University, Kobe 657-8501, Japan \\ (Correspondence should be addressed to T Sugawara; Email: terusuga@med.hokudai.ac.jp)
}

\begin{abstract}
Steroidogenic acute regulatory (StAR) protein plays a crucial role in the intramitochondrial movement of cholesterol, where P450 side chain cleavage enzyme resides. Cholesterol sulphate (CS), which is present ubiquitously in mammalian tissues, is not only a precursor of sulphated adrenal steroids but also an inhibitor of cholesterol biosynthesis. This study was designed to examine the biological roles of CS in steroidogenesis in adrenocortical cells. Human adrenocortical carcinoma H295R cells were cultured with various amounts of CS. To evaluate steroid hormone synthesis, pregnenolone production in cells was assayed. The amount of pregnenolone produced by H295R cells in culture medium, to which over $50 \mu \mathrm{g} / \mathrm{ml} \mathrm{CS}$ was added, was significantly $(P<0 \cdot 05)$ decreased compared with that produced by control cells. Western blot analysis was
\end{abstract}

performed to determine StAR protein level using whole cell extracts from cells. StAR protein level decreased when the concentration of CS in the medium was $50 \mu \mathrm{g} / \mathrm{ml}$, whereas the level of glyceraldehyde-3-phosphate dehydrogenase did not change. To examine the mechanism by which StAR gene expression is controlled, we performed RT-PCR and measured promoter activity in cells transfected with $\mathrm{pGL}_{2} \mathrm{StAR}$ reporter constructs. StAR mRNA level and promoter activity were decreased in cells. The decrease in StAR protein level is a result of the low StAR gene expression level. In conclusion, CS affects the production of steroid hormones by reducing StAR protein level in adrenocortical cells.

Journal of Endocrinology (2007) 195, 451-458

\section{Introduction}

Steroid hormone biosynthesis from cholesterol requires several enzymatic steps. The first step of steroid hormone synthesis is the conversion from cholesterol to pregnenolone by cytochrome P450 side chain cleavage enzyme (P450scc). Since the intermembrane space of mitochondria is hydrophilic, a transport system is needed for the entry of cholesterol into the inner membrane, where P450scc resides. Steroidogenic acute regulatory (StAR) protein, which mediates the rate-limiting step in the synthesis of steroid hormones, plays a key role in the intramitochondrial movement of cholesterol (Stocco \& Clark 1996, Strauss et al. 1999, Christenson \& Strauss 2000).

Cholesterol exists in serum either bound to lipoprotein (LDL or HDL) or as cholesterol sulphate (CS). Steroid sulphatase (STS) is a membrane-bound protein in the endoplasmic reticulum, which catalyzes desulphation of CS and $3 \beta$-hydroxysteroid sulphates, such as progesterone sulphate, dehydroepiandrosterone sulphate and estrone sulphate (Willemsen et al. 1988, Stein et al. 1989). STS hydrolyzes CS to provide free cholesterol in cells. STS is present ubiquitously in tissues, including steroid hormone-producing cells, ovary, testis, adrenal gland and

placenta (Martel et al. 1994). It has been shown in previous studies that STS increases StAR protein level and stimulates steroid production in cells (Sugawara \& Fujimoto 2004). Cholesterol including oxysterols is thought to enhance StAR protein translation to increase StAR protein function (Sugawara \& Fujimoto 2004). CS has been reported to be an inhibitor of steroidogenesis in isolated rat adrenal mitochondria by inhibiting cholesterol movement in the mitochondria (Lambeth et al. 1987). STS has been suggested to play an important physiological role in steroidogenic cells, but the effect of CS on steroidogenesis remains unclear (Clemens et al. 2000).

Production of steroid hormones is rapidly increased by the stimulation of trophic hormones adrenocorticotrophin, luteinizing hormone and follicle-stimulating hormone (ACTH, LH and FSH). When trophic hormones bind to their cognate receptors, increase in intracellular cAMP levels results in activation of protein kinase A (PKA). This pathway involves a mechanism that increases transcription of genes encoding the enzymes of steroid biosynthesis (Stocco \& Clark 1996). The promoter activity of human StAR gene is increased by cAMP stimulation (Sugawara et al. 1997, Sandhoff et al. 1998, Clark \& Combs 1999). This study was 
designed to examine the effects of CS on basal and cAMPstimulated steroidogenesis in adrenocortical cells.

\section{Materials and Methods}

\section{Cell culture}

Human adrenocortical carcinoma H295R cells were grown in Dulbecco's modified Eagle's medium (DMEM)/F12 containing $2 \%$ ULTROSER G (BioSepra, Cergy-Pontoise, France) and 1\% ITS Premix (Becton Dickinson and Co., Franklin Lakes, NJ, USA). Cultures of sub-confluent cells were plated so that $35 \mathrm{~mm}$ tissue culture dishes received equal numbers of cells. The culture medium was replaced with serum-free medium, and various concentrations of CS $(0-200 \mu \mathrm{g} / \mathrm{ml})$ were added to the medium. The cells were allowed to incubate for $48 \mathrm{~h}$. Some cells were treated with Br-cAMP in the culture medium. At the end of the treatment period, the media were collected for hormonal assays. In some dishes, 22R-hydroxycholesterol (22-OH cholesterol; $5 \mu \mathrm{g} / \mathrm{ml}$ ), which is a more soluble pregnenolone precursor and an intermediate in the cholesterol side chain cleavage reaction, was added to the culture medium.

\section{Pregnenolone ELISA}

Pregnenolone was measured in cell culture supernatant by ELISA using anti-pregnenolone polyclonal serum provided by Dr Yamazaki of the University of Hiroshima, HigashiHiroshima, Japan. ELISA was performed by the 'sandwich' method. Briefly, Immuno 96 MicroWell Plates (Nunc A/S, Kamstrupvej, Denmark) were coated with goat anti-rabbit IgG antibody (CHEMICON Inc., Temecula, CA, USA; $70 \mu \mathrm{g} / \mathrm{ml}$, $100 \mu \mathrm{l} /$ well) in $50 \mathrm{mM} \mathrm{NaHCO}$ buffer ( $\mathrm{pH} 9 \cdot 6$ ) overnight at $4{ }^{\circ} \mathrm{C}$. Plates were washed thrice with PBS and blocked with $2 \%$ (w/v) skim milk for $1 \mathrm{~h}$ at $37^{\circ} \mathrm{C}$. After the plates had been washed thrice with PBS, anti-pregnenolone serum $1: 1000$; $100 \mu \mathrm{l} /$ well) in PBS was added to the wells and incubated for $2 \mathrm{~h}$ at $37^{\circ} \mathrm{C}$. The plates were washed five times with PBS containing $0.05 \%$ Tween 20. Duplicate $50 \mu \mathrm{l}$ samples or standards were incubated with $1 \mu \mathrm{g} / \mathrm{ml}$ pregnenolone-3-succinate-horseradish peroxidase in $50 \mu \mathrm{l}$ PBS per well and incubated for $2 \mathrm{~h}$ at $37^{\circ} \mathrm{C}$, followed by washing five times with PBS with $0 \cdot 05 \%$ Tween 20. One hundred microlitres of peroxidase substrate solution (one tablet of 2,2'-azino-di-[3-ethylbenzthiazoline sulphonate (6)] (ABTS), Roche) in $5 \mathrm{ml}$ buffer containing ABTS (Roche) was added to the wells, and the reaction was allowed to proceed at room temperature for $30 \mathrm{~min}$. The absorbance was measured at $405 \mathrm{~nm}$. The limit of assay sensitivity was $0.5 \mathrm{ng} / \mathrm{ml}$ pregnenolone. The intra- and interassay coefficients of variation were $9 \cdot 2 \%$ and $11 \%$ respectively.

\section{Western blot analysis}

Extracts of H295R cells were harvested with RIPA buffer (50 mM Tris-HCl, 1\% Nonidet P-40, 0·1\% deoxycholate,
0.1\% SDS, $150 \mathrm{mM} \mathrm{NaCl}, 1 \mathrm{mM}$ EDTA, $1 \mathrm{mM}$ dithiothreitol, $0.1 \mathrm{mM}$ phenylmethylsulphonyl fluoride and $1 \times$ proteinase inhibitor) after transfection. Ten micrograms of cell extract were subjected to $12 \%$ SDS-PAGE. After electrophoresis, the gels were transferred to polyvinylidene difluoride (PVDF) membranes for immunodetection with anti-StAR rabbit serum, anti-STS serum, anti-cytochrome C IgG, anti-glyceraldehyde-3-phosphate dehydrogenase (GAPDH) IgG and anti-P450scc serum. Anti-STS serum was prepared by immunization of rabbits with human STS, as described previously (Sugawara et al. 1994). Dr Jerome F Strauss III of the Virginia Commonwealth University, Richmond, USA, generously provided human anti-StAR serum. Human anti-P450scc was a gift from Dr Toshihiro Tajima of the Hokkaido University School of Medicine, Sapporo, Japan. Anti-cytochrome $C \operatorname{IgG}$ was purchased from Santa Cruz Biotechnology Inc. (Santa Cruz, CA, USA), and anti-GAPDH IgG was from American Research Products Inc., (Belmont, MA, USA). The signal was detected by chemiluminescence using ECL or ECL Plus Western Blotting Detection Reagents (Amersham Pharmacia Biotech). The relative abundance of StAR protein levels was quantified using NIH Image $1.55 \mathrm{f}$ (Ohlendorf Research Inc., Ottawa, IL, USA), normalized against levels of GAPDH protein levels and expressed as a percentage of the control value.

\section{Transfection and luciferase assays}

$\mathrm{pGL}_{2}$-Basic was purchased from Promega Corp. A luciferase reporter gene for the $1.3 \mathrm{~kb}$ human StAR promoter was used as the $\mathrm{pGL}_{2}-1.3 \mathrm{~kb}$ StAR vector as described previously (Sugawara et al. 2001). A $\beta$-galactosidase expression vector (pCH110; Amersham Pharmacia Biotech) was used for normalization of luciferase data. National Cancer Institute (NCI)-H295R cells at 80-60\% confluence were transfected with $0.5 \mu \mathrm{g} \mathrm{pGL}_{2}$ plasmid and $0.5 \mu \mathrm{g}$ pCH110 using $4 \mu \mathrm{l}$ Lipofectamine 2000 (Roche Molecular Biochemicals) per $1 \mu \mathrm{g}$ DNA. $\mathrm{pGL}_{2}-1 \cdot 3 \mathrm{~kb}$ StAR plasmids and $\mathrm{pCH} 110$ were transfected into NCI-H295R cells. After $3 \mathrm{~h}$, the culture medium was replaced with serum-free medium, and CS $(100 \mu \mathrm{g} / \mathrm{ml})$ was added to the medium. Some cells were treated with 8 -Br-cAMP $(1 \mathrm{mM})$ during the final $24 \mathrm{~h}$ of culture. Cells were harvested after a 48-h culture period, and the cell lysate was subjected to a luciferase assay. Luciferase assays were performed using a Luciferase Assay System (Promega). Each treatment group contained triplicate cultures, and each experiment was repeated thrice.

\section{Reverse transcription PCR (RT-PCR)}

Total RNA was isolated from $\mathrm{H} 295 \mathrm{R}$ cells. cDNA synthesis was carried out at $37^{\circ} \mathrm{C}$ for $60 \mathrm{~min}$ using $150 \mathrm{pmol}$ oligo dT as a primer, $1 \mu \mathrm{g}$ total RNA and 200 units of SuperScript II Reverse Transcriptase (Life Technologies Inc./BRL). Twenty microlitres of reaction mixture for reverse transcriptase contained $50 \mathrm{mM}$ Tris- $\mathrm{HCl}(\mathrm{pH} 8 \cdot 3), 75 \mathrm{mM} \mathrm{KCl}, 3 \mathrm{mM} \mathrm{MgCl} 2,20 \mathrm{mM}$ 
dithiothreitol and $0.5 \mathrm{mM}$ each of dATP, dCTP, dGTP and dTTP. Then, PCRs were carried out with $1 \mu \mathrm{l}$ reverse transcription reaction product using the following oligonucleotide primers designed for amplification of StAR: sense, 5'-GCAGCAGCAGCGGCGGCAGCAG-3'; antisense, $5^{\prime}$-CTCTTGGTTGCTAAGGAT- $3^{\prime}$. Fifty microlitres of the PCR mixture contained $10 \mathrm{mM}$ Tris- $\mathrm{HCl}(\mathrm{pH} 8 \cdot 3), 50 \mathrm{mM}$ $\mathrm{KCl}, 1.5 \mathrm{mM} \mathrm{MgCl}_{2}, 0.2 \mathrm{mM}$ dNTPs and $10 \mathrm{pmol}$ each of the primers. The reaction was subjected to 22 cycles of denaturing at $94{ }^{\circ} \mathrm{C}$ for $45 \mathrm{~s}$, annealing at $55^{\circ} \mathrm{C}$ for $45 \mathrm{~s}$ and extension at $72{ }^{\circ} \mathrm{C}$ for $1 \mathrm{~min}$. RT-PCR for GAPDH (25 cycles) as a control was performed using the following primers for GAPDH: sense, 5'-TGCCGTCTAGAAAAACCTGC-3'; antisense, $5^{\prime}$-ACCCTGTTGCTGTAGCCAAA-3'. The relative abundance of StAR mRNA expression was quantified using NIH Image $1.55 \mathrm{f}$ (Ohlendorf Research, Inc., Ottawa, IL, USA), normalized against levels of GAPDH mRNA expression and expressed as a percentage of the control value.

\section{Data analysis}

Values are presented as means \pm s.E.M. Significance in difference between experimental values was determined using Student's unpaired $t$ test, and one-way ANOVA was used to test differences in repeated measures across experiments. Significant results from ANOVA were further analyzed by Tukey's post hoc test. $P<0 \cdot 05$ was considered significant.

\section{Results}

To examine the effect of CS on the production of steroid hormones by cells, we assayed pregnenolone production, which is the first step of steroid hormone synthesis. When $50 \mu \mathrm{g} / \mathrm{ml}$ CS was added to the culture medium, the production of pregnenolone by $\mathrm{H} 295 \mathrm{R}$ cells was significantly reduced $24 \cdot 1 \%$ compared with that without the addition of CS. Pregnenolone concentration in the medium containing over $50 \mu \mathrm{g} / \mathrm{ml} \mathrm{CS}$ was significantly decreased compared with that in the medium containing no CS. When 22-OH cholesterol was added to the culture medium, the production of pregnenolone increased, even in the culture media containing CS, indicating that pregnenolone synthesis in the presence of 22-OH cholesterol was not affected by CS treatment (Fig. 1).

We examined the time course of pregnenolone production in order to predict the mechanism by which CS affects steroidogenesis. We measured pregnenolone concentrations of medium samples that were collected at 24,48 and $72 \mathrm{~h}$ after the addition of CS to the culture medium of H295R cells. Although pregnenolone concentration in the medium without and with CS $(2$ and $10 \mu \mathrm{g} / \mathrm{ml})$ increased with the elapse of time, pregnenolone concentration reached a plateau at $48 \mathrm{~h}$ after the addition of $50 \mu \mathrm{g} / \mathrm{ml} \mathrm{CS}$ to the culture medium (Fig. 2A). When $1 \mathrm{mM} \mathrm{Br-cAMP}$ was added to the culture medium, pregnenolone production in the cells increased, and the rate of increase in pregnenolone production with

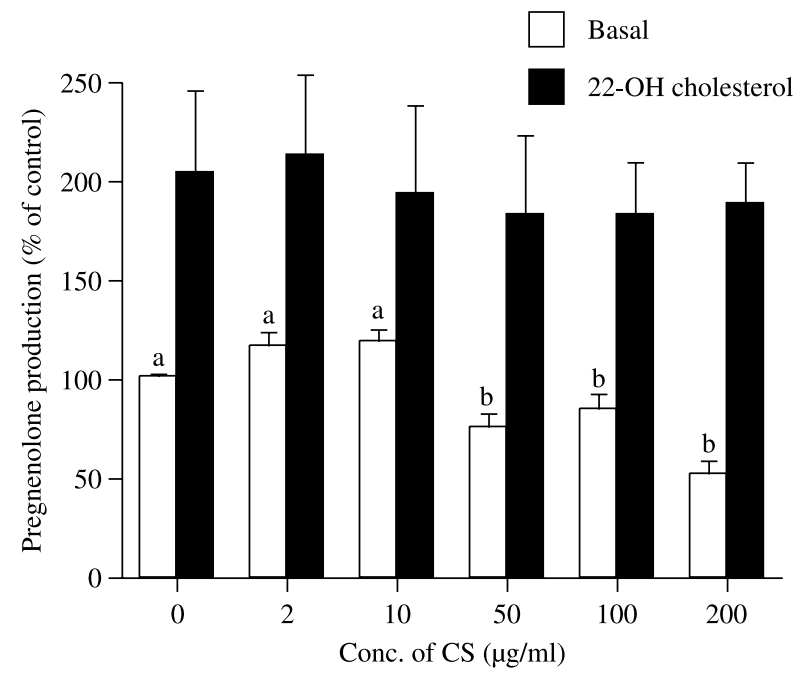

Figure 1 Effect of CS on steroidogenesis in cells. (A) Pregnenolone concentration in $\mathrm{NCl}-\mathrm{H} 295 \mathrm{R}$ cells was assayed in culture media containing CS $(0-200 \mu \mathrm{g} / \mathrm{ml})$ (open bars). Then, 22-OH cholesterol was added to some culture dishes (black). Values are expressed as percentages of the control. Results presented are the means \pm s.E.M. from three separate experiments. ${ }^{a, b}$ Groups with different letters are significantly different $(P<0 \cdot 05)$ from each other, as determined by ANOVA followed by Tukey's post hoc test.

$50 \mu \mathrm{g} / \mathrm{ml} \mathrm{CS}$ was significantly different from that without $\mathrm{CS}$ or with 2 or $10 \mu \mathrm{g} / \mathrm{ml} \mathrm{CS}$. At $48 \mathrm{~h}$ after the addition of CS to the culture medium, pregnenolone production with $50 \mu \mathrm{g} / \mathrm{ml} \mathrm{CS}$ was significantly decreased from that without CS or with 2 or $10 \mu \mathrm{g} / \mathrm{ml} \mathrm{CS} \mathrm{(Fig.} \mathrm{2B).} \mathrm{Thus,} \mathrm{the} \mathrm{effect} \mathrm{of} \mathrm{CS}$ on basal pregnenolone production appears in the early hours after the addition of CS to the culture medium.

To determine the effect of CS on StAR protein level, we performed western blot analysis of extracts from H295R cells. The StAR protein levels decreased with $50 \mu \mathrm{g} / \mathrm{ml} \mathrm{CS}$ (Fig. 3A). When $50 \mu \mathrm{g} / \mathrm{ml} \mathrm{CS}$ was added to the culture medium, the level of mature StAR protein $(30 \mathrm{kDa})$ was reduced $32 \cdot 4 \%$ compared with that without the addition of $\mathrm{CS}$. When the medium contained over $50 \mu \mathrm{g} / \mathrm{ml} \mathrm{CS}$, the level of mature StAR protein $(30 \mathrm{kDa})$ was significantly decreased compared with that in the medium containing no CS. The level of pre-StAR protein $(37 \mathrm{kDa})$ was also significantly decreased compared with that in the medium without CS when CS concentration in the culture medium was over $100 \mu \mathrm{g} / \mathrm{ml}$ (Fig. 3B).

STS is an endoplasmic reticulum protein, and its substrate is CS. Cytochrome $C$ is present in the mitochondria matrix and is associated with apoptosis. P450scc is a steroidogenic enzyme and it cleaves the side chain of cholesterol and synthesizes pregnenolone from cholesterol. To determine whether the effect of CS on StAR protein level is specific, and whether the decrease in steroid hormone production depends on StAR protein, we performed western blot analysis using StAR, STS, cytochrome $C$ and GAPDH antibody. Although the StAR protein level clearly decreased, the protein levels of 
A
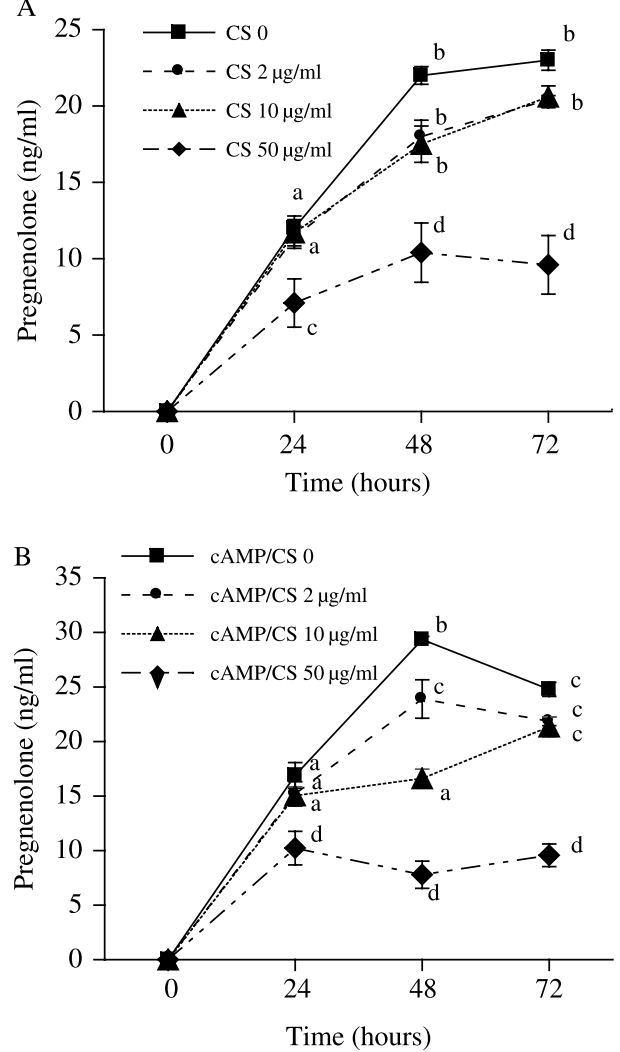

Figure 2 Time courses of pregnenolone production in basal and cAMP-stimulated conditions in the presence of CS. Cultures of subconfluent $\mathrm{NCl}-\mathrm{H} 295 \mathrm{R}$ cells were plated so that $35 \mathrm{~mm}$ culture dishes received equal numbers of cells. The next day the culture medium was replaced with serum-free medium, and CS $(0-50 \mu \mathrm{g} / \mathrm{ml})$ was added to the medium. Cells were incubated without (A) and 8-Br-cAMP (1 mM) (B). Culture medium samples were collected at various times and kept at $-80{ }^{\circ} \mathrm{C}$ until assay of pregnenolone concentration. Values presented are the means \pm S.E.M. of pregnenolone production from three separate experiments. ${ }^{a-d}$ Groups with different letters are significantly different $(P<0 \cdot 05)$ from each other.

STS, cytochrome $C$ and GAPDH did not change when $\mathrm{H} 295 \mathrm{R}$ cells were cultured in the medium containing $200 \mu \mathrm{g} / \mathrm{ml} \mathrm{CS}$ (Fig. 4A). The protein level of P450scc increased in response to Br-cAMP stimulation. P450scc protein level did not change in the presence of CS, and the protein level increased in response to $\mathrm{Br}$-cAMP stimulation (Fig. 4B). CS had no effect on P450scc protein level, and the effect of CS is specific to StAR protein level.

To clarify the effect of CS on steroidogenesis, RT-PCR was performed to examine the effect of CS on StAR gene expression. The basal StAR gene expression level in H295R cells in the medium containing of $50 \mu \mathrm{g} / \mathrm{ml}$ CS was decreased. Although StAR gene expression level increased with Br-cAMP stimulation, StAR gene expression level in H295R cells also decreased in the culture medium containing CS (Fig. 5A). When the medium contained $50 \mu \mathrm{g} / \mathrm{ml} \mathrm{CS}$, the basal StAR
A

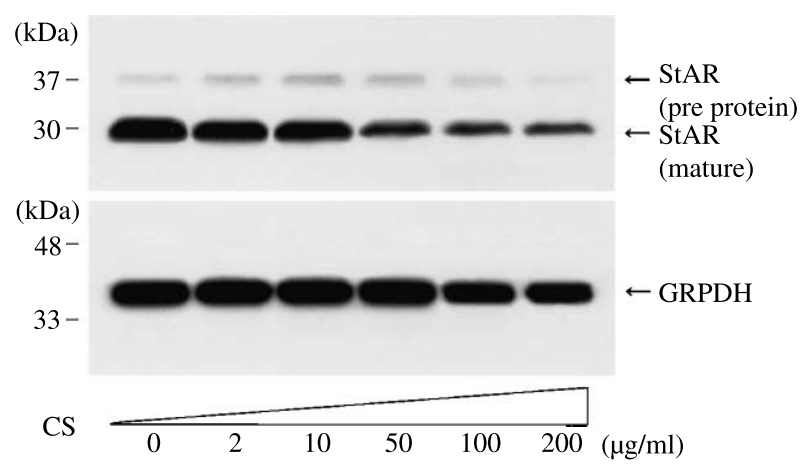

B

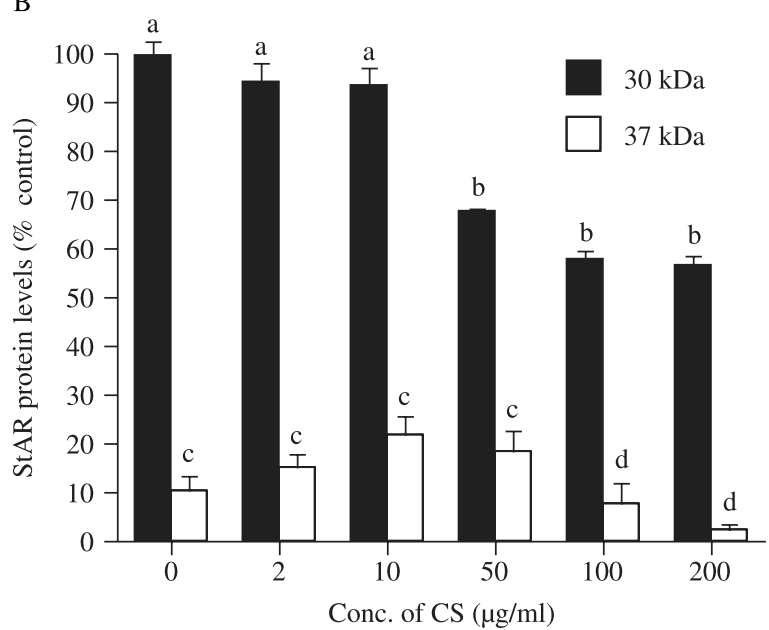

Figure 3 Effect of CS on StAR protein level in cells. NCI-H295R cells were plated onto $35 \mathrm{~mm}$ culture dishes. The next day the culture medium was replaced with serum-free medium, and CS $(0-200 \mu \mathrm{g} / \mathrm{ml})$ was added to the medium. After $24 \mathrm{~h}$, extracts were harvested for western blot analysis. Ten micrograms of cell extract were then subjected to $12 \%$ SDS-PAGE. After electrophoresis, the gels were transferred to PVDF membranes for immunodetection with anti-StAR serum and anti-GAPDH IgG. The signal was detected by chemiluminescence using ECL western blotting detection reagents. (B) The abundance of StAR protein was quantified by densitometric scanning. StAR pre-protein $(37 \mathrm{kDa})$ and mature protein $(30 \mathrm{kDa})$ abundance ratios are expressed relative to the amount of GAPDH protein in cells. Values are expressed as percentages of the control. Results for StAR protein levels are presented as means \pm S.E.M. from three separate experiments. $(a-d)$, Groups with different letters are significantly different $(P<0 \cdot 01)$ from each other.

gene expression level was significantly decreased compared with that in the medium containing no CS. The cAMP-stimulated StAR gene expression level was also significantly decreased compared with that in the medium without CS, when CS concentration in the culture medium was $100 \mu \mathrm{g} / \mathrm{ml}$. CS had an effect on both the basal StAR gene expression and the cAMPstimulated StAR gene expression (Fig. 5B).

To confirm that CS has an effect on StAR gene expression, we analyzed StAR promoter activity of H295R cells with 
A

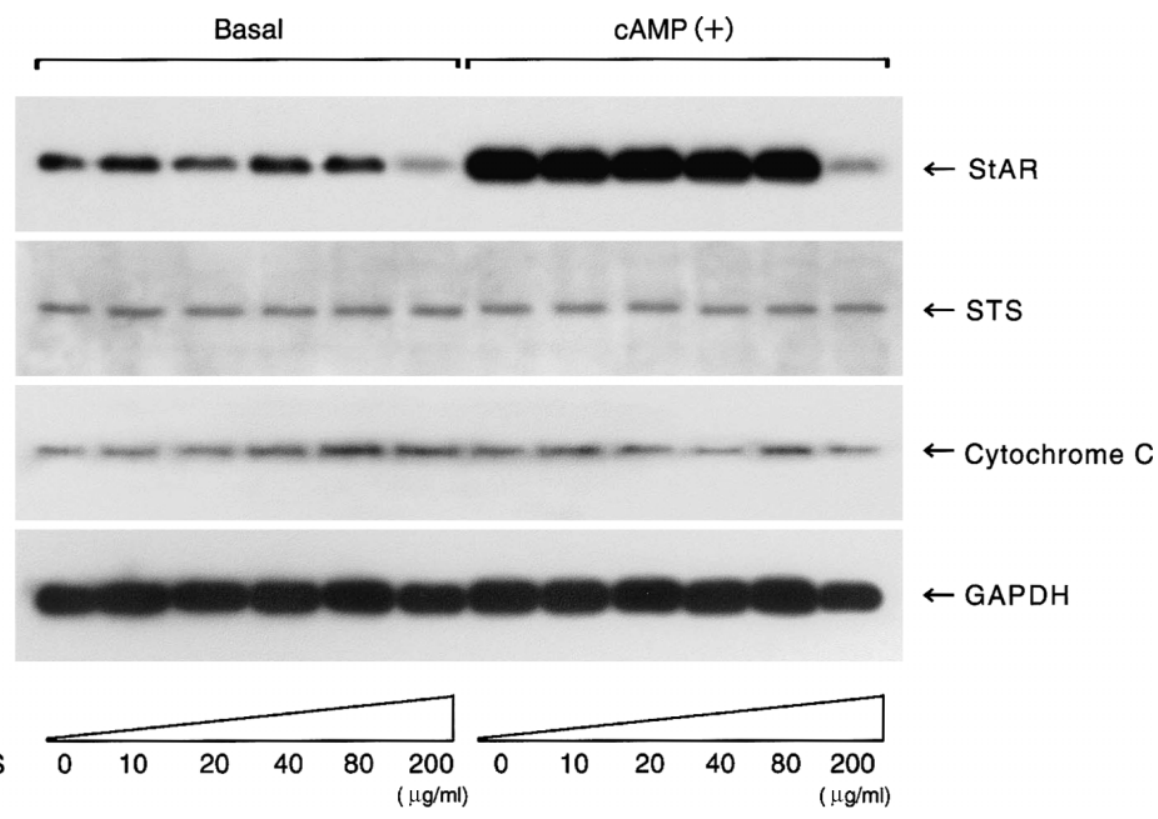

B

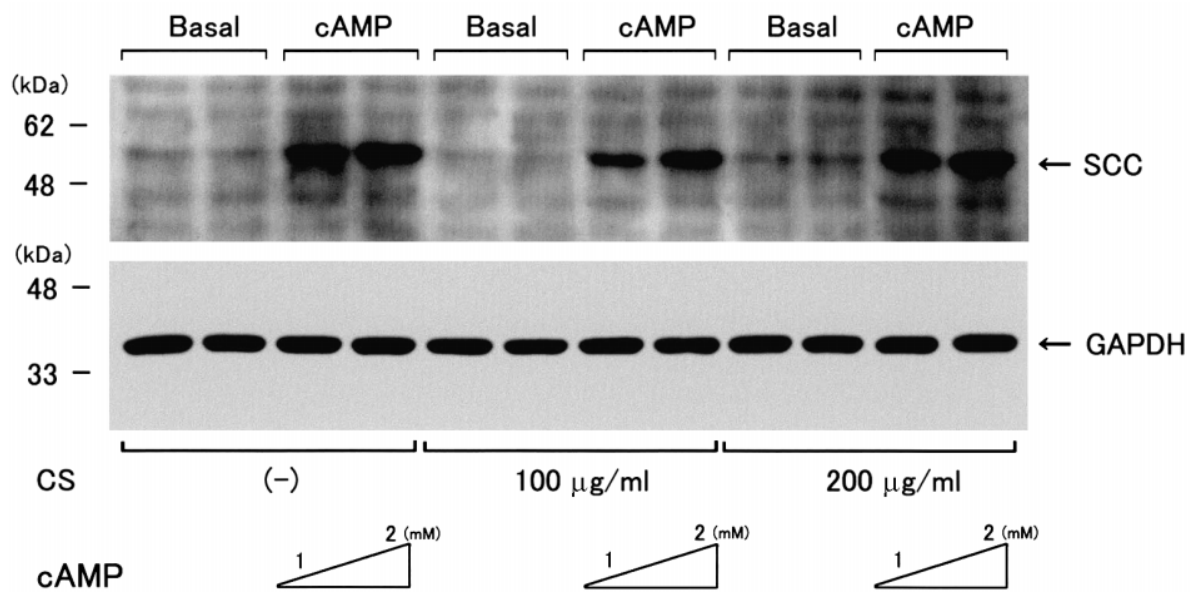

Figure 4 Specific effect on StAR protein level in the presence of CS. NCl-H295R cells were cultured with serum-free medium containing CS $(0-200 \mu \mathrm{g} / \mathrm{ml})$. After $48 \mathrm{~h}$, cell extracts were collected for western blot analysis. Immunodetection was performed with anti-StAR serum, anti-STS serum, anti-cytochrome C IgG, anti-GAPDH IgG (A) and P450scc serum (B). Some cells were treated with Br-cAMP (1 mM and 2 mM) during the final $24 \mathrm{~h}$ of culture. The experiment was repeated thrice.

$\mathrm{CS}$ in the culture medium. Although the StAR promoter activity is stimulated by $\mathrm{Br}$-cAMP regardless of the presence of CS, the basal and cAMP-stimulated StAR promoter activity levels were significantly decreased when the culture medium contained $50 \mathrm{ng} / \mathrm{ml}$ CS (Fig. 6A). Thus, CS affects the StAR promoter activity. To determine whether the effect of CS on StAR gene expression is specific, we assayed the StAR promoter activity of cells in a culture medium to which 25-hydroxycholesterol (25-OHC) and lipoproteincontaining cholesterol had been added. Although the StAR promoter activity level did not decrease in cells in the medium containing 25-OHC and lipoprotein, the promoter activity level of StAR was significantly decreased compared with that of the control in both basal and cAMP stimulation conditions (Fig. 6B). CS has a specific effect on StAR promoter activity, and the decrease in StAR gene expression level is a result of the decrease in StAR gene promoter activity. CS affects the StAR gene expression by controlling StAR promoter activity. The decrease in pregnenolone production results from the decreased StAR protein level, and the decrease in StAR protein level results from the control of StAR gene expression. 

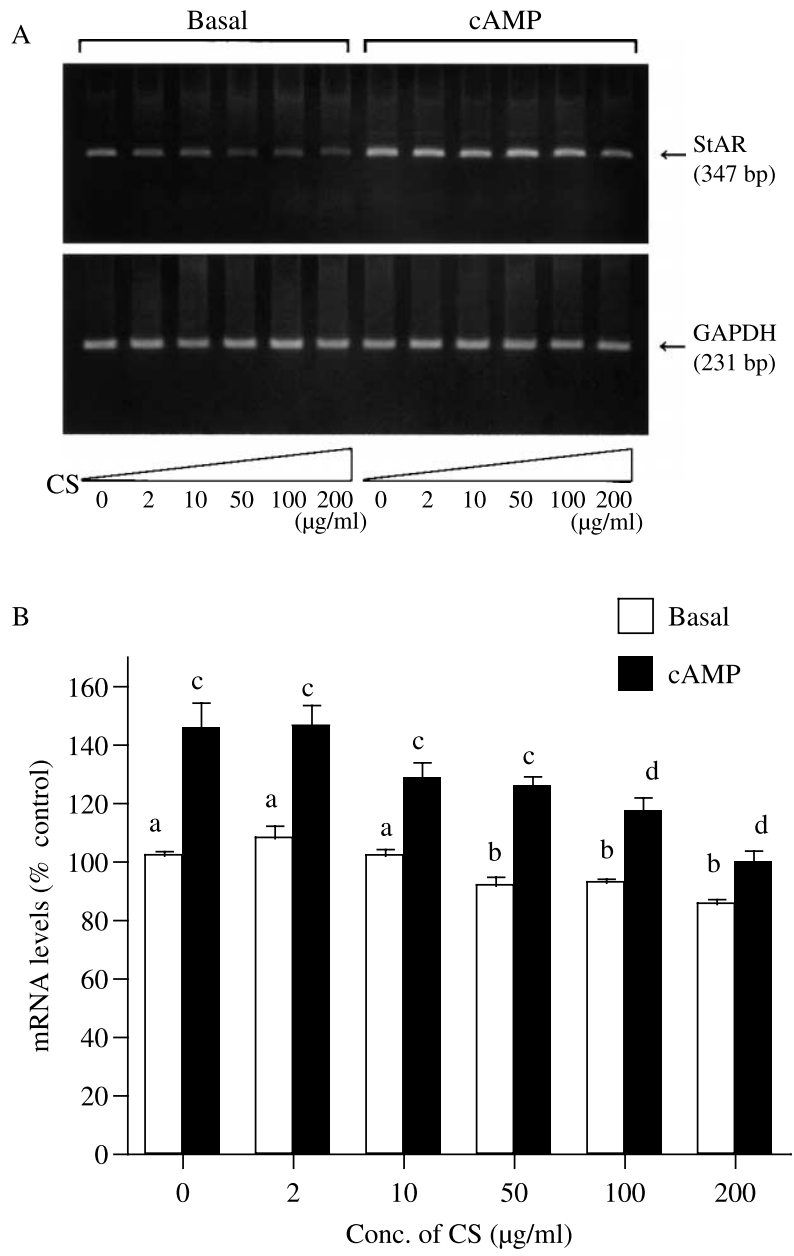

Figure 5 StAR gene expression in $\mathrm{NCl}-\mathrm{H} 295 \mathrm{R}$ cells in culture medium with CS. RT-PCR was performed using mRNA extracted from $\mathrm{NCl}-\mathrm{H} 295 \mathrm{R}$ cells. $\mathrm{NCl}-\mathrm{H} 295 \mathrm{R}$ cells were cultured with serumfree medium containing CS $(0-200 \mu \mathrm{g} / \mathrm{ml})$ for $48 \mathrm{~h}$. Cells were treated with 8-Br-cAMP $(1 \mathrm{mM})$ during the final $24 \mathrm{~h}$ of culture or not treated with $8-\mathrm{Br}-\mathrm{CAMP}$. The sizes of PCR products were $347 \mathrm{bp}$ (StAR) and 231 bp (GAPDH). (B) The StAR mRNA expression levels were quantified by densitometric scanning. Results were normalized for the amount of GAPDH, expressed as a percentage of the control. The values for StAR mRNA levels are presented as means \pm S.E.M. from three separate experiments. ${ }^{\text {a-d }}$ Groups with different letters are significantly different $(P<0 \cdot 05)$ from each other.

\section{Discussion}

CS is a substrate of STS and is desulphated into cholesterol. Synthesis of cholesterol from CS is different from de novo synthesis of cholesterol in the endoplasmic reticulum, and the synthesized cholesterol is redistributed to all parts of the cell (Schorderet et al. 1988). Overexpression of STS results in an increase in StAR protein level and an increase in the production of steroid hormones (Sugawara \& Fujimoto 2004). CS is desulphated by STS and increases the amounts of free cholesterol in cells. It has been shown that free cholesterol binds to StAR
A
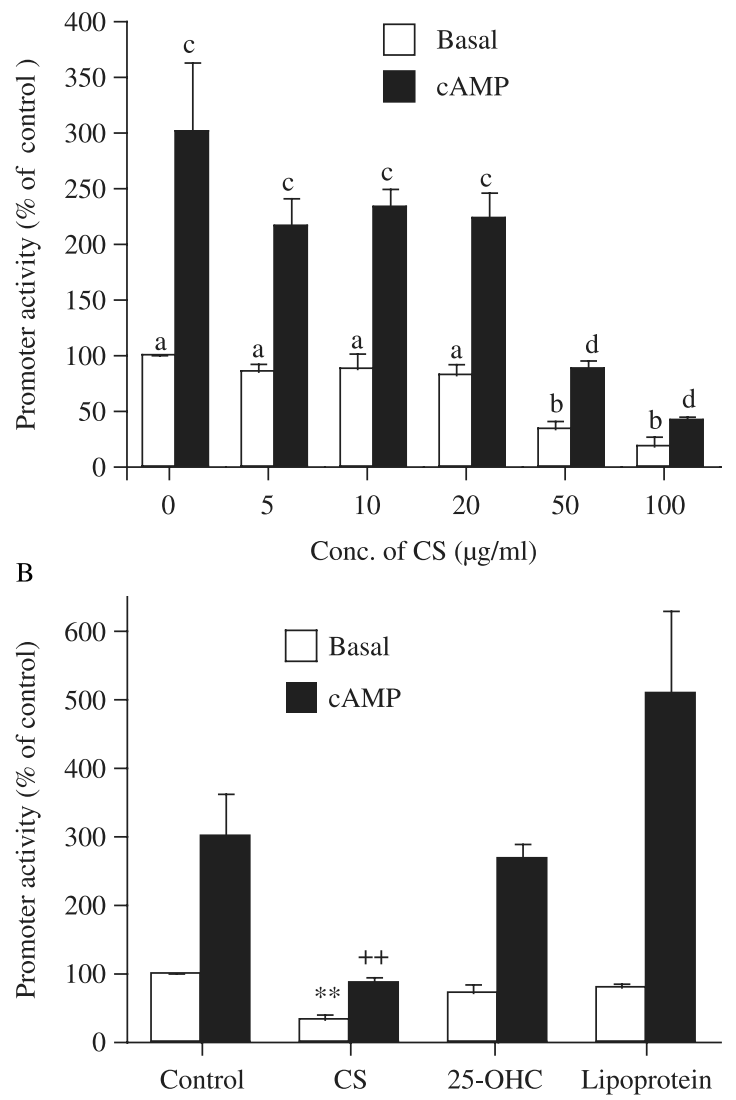

Figure 6 StAR promoter activity in $\mathrm{NCl}-\mathrm{H} 295 \mathrm{R}$ cells. (A) $\mathrm{pGL}_{2}$ $1 \cdot 3 \mathrm{~kb}$ StAR plasmids and $\mathrm{pCH} 110$ were transfected into $\mathrm{NCl}-\mathrm{H} 295 \mathrm{R}$ cells. Some cells were treated with 8-Br-cAMP $(1 \mathrm{mM})$. The cell lysate was subjected to a luciferase assay. The results are presented as means \pm s.E.M. from three experiments. (a-d), Groups with different letters are significantly different $(P<0 \cdot 05)$ from each other. (B) The human $1.3 \mathrm{~kb}$ StAR promoter and $\mathrm{pCH} 110$ were transfected into $\mathrm{NCl}-\mathrm{H} 295 \mathrm{R}$ cells. After $3 \mathrm{~h}$, the culture medium was replaced with serum-free medium, and CS $(50 \mu \mathrm{g} / \mathrm{ml})$,

25-hydroxylcholesterol $(50 \mu \mathrm{g} / \mathrm{ml}$ ) and lipoprotein (containing $50 \mu \mathrm{g} / \mathrm{ml}$ cholesterol) were added to the medium. Some cells were treated with 8-Br-cAMP $(1 \mathrm{mM})$ during the final $24 \mathrm{~h}$ of culture. Cells were harvested after a 48-h culture period, and the cell lysate was subjected to a luciferase assay. The results are presented as means \pm S.E.M. from three experiments. ${ }^{* *}$ Significantly different from basal promoter activity of control. ${ }^{++}$Significantly different from promoter activity of control with $1 \mathrm{mM} 8$-Br-CAMP. ${ }^{* *,+}+P<0 \cdot 01$.

protein in cells, resulting in a decrease in StAR protein degradation and also an increase in the translation of StAR protein (Sugawara \& Fujimoto 2004). Transfection of COS-1 cells with a StAR expression vector and a P450scc system resulted in an increase in the production of steroid hormones (Sugawara \& Fujimoto 2004), but in steroidogenic cells, H295R cells, steroid hormone production did not increase. The protein level of STS was not increased in steroidogenic cells even when $\mathrm{CS}$ was added to the culture medium. The effect of CS seems to be specific to the StAR protein because levels of other proteins, 
STS, SCC and GAPDH, did not change. The results showing that the production of pregnenolone was not reduced by CS treatment in the presence of $22-\mathrm{OH}$ cholesterol, a membranepermeable form of cholesterol, support the specific effects of CS to StAR protein. The specific effect of CS on the StAR gene is a result of an effect on the StAR gene promoter activity in cells. Therefore, the decrease in pregnenolone production results from the decreased StAR protein level, and the decrease in StAR protein results from the control of StAR gene expression.

Eukaryotic cells have membranes composed of phospholipids and proteins. Cholesterol and CS are also important components of cell membranes. CS has been shown to protect red blood cells against osmotic lysis and function as a membranestabilizing agent at physiological concentrations. The effect of CS on cell membranes requires an amphipathic property linked to the sulphate group at the 3 position of the sterol ring and the cholesterol side chain (Strott \& Higashi 2003). On the contrary, a high concentration of CS added to a culture mixture of erythrocytes caused haemolysis because of the detergent-like effect of CS (Przybylska et al. 1998). Indeed, CS has some effects on cell membranes and also seems to have an effect on protein synthesis in cells. Although the protein levels of STS, GAPDH, cytochrome $C$ and $\mathrm{P} 450 \mathrm{scc}$ were not changed by the addition of CS to the culture medium, StAR protein synthesis was affected by CS. StAR protein is synthesized in the cytosol and is imported into the mitochondria matrix (Reed et al. 2005). StAR protein could not undergo its proper protein processing, resulting in its degradation in the cell, because the mitochondrial membrane may have been affected by CS and resulted in impairment of StAR protein import to the mitochondria matrix. This also seems to be one of causes of the decrease in StAR protein level.

Sterol sulphate can easily be transported from serum to cells through cell membranes by the organic anion transporting polypeptide-B (Reed et al. 2005). Nuclear receptors are liganddependent transcription factors that play important roles in many biological functions (Mangelsdorf et al. 1995). Recently, ligands of retinoic acid receptor-related orphan receptor $\alpha$ $(\operatorname{ROR} \alpha)$, a previously reported orphan receptor, have been found. Cholesterol and cholesterol derivatives have been reported to be natural ligands (Kallen et al. 2002, Bitsch et al. 2003). CS has also been suggested from $X$-ray determination of its crystal structure to be a ligand of ROR $\alpha$ (Kallen et al. 2004). The $5^{\prime}$ upper regions of human StAR gene have been reported to contain several response elements of transcription factors (Strauss et al. 1999). In the present study, even when CS was added to the culture medium, the promoter activity ofStAR was decreased. CS has been shown not only to inhibit cholesterol esterification and HMG-CoA reductase activity and to modulate intracellular cholesterol level (Williams et al. 1985), but also to regulate promoter activity of the StAR gene. ROR $\alpha$ has been shown to be associated with regulation of plasma cholesterol levels via apolipoprotein (Vu-Dac et al. 1997, Raspe et al. 2001), and its expression is present in several organs, including the testis (Steinmayr et al. 1998, Boukhtouche et al. 2004). CS is not only a precursor of steroid hormones but also seems to be associated with tissue-specific signal transduction and differentiation.

CS decreases synthesis of steroid hormones by reducing StAR protein level. Further study is needed to clarify the important roles of CS in steroidogenic cells.

\section{Acknowledgements}

This study was supported by Grants-in-Aid for Scientific Research from the Ministry of Education, Science and Culture, Japan. The authors declare that there is no conflict of interest that would prejudice the impartiality of this scientific work.

\section{References}

Bitsch F, Aichholz R, Kallen J, Geisse S, Fournier B \& Schlaeppi JM 2003 Identification of natural ligands of retinoic acid receptor-related orphan receptor alpha ligand-binding domain expressed in $\mathrm{Sf} 9$ cells - a mass spectrometry approach. Analytical Biochemistry 323 139-149.

Boukhtouche F, Mariani J \& Tedgui A 2004 The 'CholesteROR' protective pathway in the vascular system. Arteriosclerosis, Thrombosis, and Vascular Biology 24 637-643.

Christenson LK \& Strauss JF, III 2000 Steroidogenic acute regulatory protein (StAR) and the intramitochondrial translocation of cholesterol. Biochimica et Biophysica Acta 1529 175-187.

Clark BJ \& Combs R 1999 Angiotensin II and cyclic adenosine 3',5'monophosphate induce human steroidogenic acute regulatory protein transcription through a common steroidogenic factor-1 element. Endocrinology 140 4390-4398.

Clemens JW, Kabler HL, Sarap JL, Beyer AR, Li PK \& Selcer KW 2000 Steroid sulfatase activity in the rat ovary, cultured granulosa cells, and a granulosa cell line. Journal of Steroid Biochemistry and Molecular Biology 75 245-252.

Kallen JA, Schlaeppi JM, Bitsch F, Geisse S, Geiser M, Delhon I \& Fournier B 2002 X-ray structure of the hRORalpha LBD at $1.63 \mathrm{~A}$ : structural and functional data that cholesterol or a cholesterol derivative is the natural ligand of RORalpha. Structure 10 1697-1707.

Kallen J, Schlaeppi JM, Bitsch F, Delhon I \& Fournier B 2004 Crystal structure of the human RORalpha Ligand binding domain in complex with cholesterol sulfate at 2.2 A. Journal of Biological Chemistry 279 14033-14038.

Lambeth JD, Xu XX \& Glover M 1987 Cholesterol sulfate inhibits adrenal mitochondrial cholesterol side chain cleavage at a site distinct from cytochrome P-450scc. Evidence for an intramitochondrial cholesterol translocator. Journal of Biological Chemistry 262 9181-9188.

Mangelsdorf DJ, Thummel C, Beato M, Herrlich P, Schutz G, Umesono K, Blumberg B, Kastner P, Mark M, Chambon P et al. 1995 The nuclear receptor superfamily: the second decade. Cell $\mathbf{8 3} 835-839$.

Martel C, Melner MH, Gagne D, Simard J \& Labrie F 1994 Widespread tissue distribution of steroid sulfatase, 3 beta-hydroxysteroid dehydrogenase/delta 5-delta 4 isomerase ( 3 beta-HSD), 17 beta-HSD 5 alpha-reductase and aromatase activities in the rhesus monkey. Molecular and Cellular Endocrinology 104 103-111.

Przybylska M, Faber M, Zaborowski A \& Bryszewska M 1998 Cholesterol sulfate induces changes in human erythrocyte thermostability. Biochemistry and Molecular Biology International 46 399-410.

Raspe E, Duez H, Gervois P, Fievet C, Fruchart JC, Besnard S, Mariani J, Tedgui A \& Staels B 2001 Transcriptional regulation of apolipoprotein C-III gene expression by the orphan nuclear receptor RORalpha. Journal of Biological Chemistry 276 2865-2871.

Reed MJ, Purohit A, Woo LW, Newman SP \& Potter BV 2005 Steroid sulfatase: molecular biology, regulation, and inhibition. Endocrine Reviews $\mathbf{2 6}$ 171-202. 
Sandhoff TW, Hales DB, Hales KH \& McLean MP 1998 Transcriptional regulation of the rat steroidogenic acute regulatory protein gene by steroidogenic factor 1. Endocrinology 139 4820-4831.

Schorderet DF, Keitges EA, Dubois PM \& Gartler SM 1988 Inactivation and reactivation of sex-linked steroid sulfatase gene in murine cell culture. Somatic Cell and Molecular Genetics 14 113-121.

Stein C, Hille A, Seidel J, Rijnbout S, Waheed A, Schmidt B, Geuze H \& von Figura K 1989 Cloning and expression of human steroid-sulfatase. Membrane topology, glycosylation, and subcellular distribution in BHK-21 cells. Journal of Biological Chemistry 264 13865-13872.

Steinmayr M, Andre E, Conquet F, Rondi-Reig L, Delhaye-Bouchaud N, Auclair N, Daniel H, Crepel F, Mariani J, Sotelo C et al. 1998 Staggerer phenotype in retinoid-related orphan receptor alpha-deficient mice. PNAS 95 3960-3965.

Stocco DM \& Clark BJ 1996 Regulation of the acute production of steroids in steroidogenic cells. Endocrine Reviews 17 221-244.

Strauss JF, III, Kallen CB, Christenson LK, Watari H, Devoto L, Arakane F, Kiriakidou M \& Sugawara T 1999 The steroidogenic acute regulatory protein (StAR): a window into the complexities of intracellular cholesterol trafficking. Recent Progress in Hormone Research 54 369-394.

Strott CA \& Higashi Y 2003 Cholesterol sulfate in human physiology: what's it all about? Journal of Lipid Research 44 1268-1278.

Sugawara T \& Fujimoto S 2004 The potential function of steroid sulphatase activity in steroid production and steroidogenic acute regulatory protein expression. Biochemical Journal 380 153-160.

Sugawara T, Honke K, Gasa S, Tanaka T, Fujimoto S \& Makita A 1994 Serum levels of steroid sulfatase protein in gynecologic carcinomas. Clinica Chimica Acta 226 13-20.
Sugawara T, Kiriakidou M, McAllister JM, Holt JA, Arakane F \& Strauss JF, III 1997 Regulation of expression of the steroidogenic acute regulatory protein (StAR) gene: a central role for steroidogenic factor 1. Steroids 62 5-9.

Sugawara T, Abe S, Sakuragi N, Fujimoto Y, Nomura E, Fujieda K, Saito M \& Fujimoto S 2001 RIP 140 modulates transcription of the steroidogenic acute regulatory protein gene through interactions with both SF-1 and DAX-1. Endocrinology 142 3570-3577.

Vu-Dac N, Gervois P, Grotzinger T, De Vos P, Schoonjans K, Fruchart JC, Auwerx J, Mariani J, Tedgui A \& Staels B 1997 Transcriptional regulation of apolipoprotein A-I gene expression by the nuclear receptor RORalpha. Journal of Biological Chemistry 272 22401-22404.

Willemsen R, Kroos M, Hoogeveen AT, van Dongen JM, Parenti G, van der Loos CM \& Reuser AJ 1988 Ultrastructural localization of steroid sulphatase in cultured human fibroblasts by immunocytochemistry: a comparative study with lysosomal enzymes and the mannose 6-phosphate receptor. Histochemical Journal 20 41-51.

Williams ML, Hughes-Fulford M \& Elias PM 1985 Inhibition of 3-hydroxy3-methylglutaryl coenzyme A reductase activity and sterol synthesis by cholesterol sulfate in cultured fibroblasts. Biochimica et Biophysica Acta $\mathbf{8 4 5}$ 349-357.

\section{Received in final form 30 September 2007}

Accepted 2 October 2007

Made available online as an Accepted Preprint 2 October 2007 